\title{
JURISDICTION IN THE COURT OF CLAIMS: FOREIGN PLAINTIFFS AND THE RECIPROCITY STATUTE
}

\section{$\mathrm{I}_{\mathrm{N}}$ Nippon Hodo Co. v. United States ${ }^{2}$ the Court of Claims adopted} a solicitous attitude toward the claims of foreign plaintiffs against the United States where jurisdiction depends on the existence of reciprocity. Two Japanese corporate plaintiffs bringing contract suits against the Government ${ }^{2}$ asserted jurisdiction under both the reciprocity provisions of section 2502 of the Judicial Code ${ }^{3}$ and under the national treatment provision of the Treaty of Friendship, Commerce and Navigation between the United States and Japan. ${ }^{4}$ The Court of Claims, relying solely on section 2502 , permitted the plaintiffs to maintain their suits. ${ }^{5}$

Section 2502 grants foreign plaintiffs the right to sue the United States in its courts if a reciprocal right is afforded to an American citizen in the plaintiff's country. ${ }^{6}$ The Government contended that the statute required reciprocity in specie, i.e., that it was necessary to show that an

\footnotetext{
${ }^{1}$ Nippon Hodo Co. v. United States; Fuiji Sangyo Kabushiki Kaisha v. United States, 285 F.2d 766 (Ct. Cl.), rehearing denied, 285 F.2d 766 (Ct. Cl. 1961).

${ }^{2}$ The plaintiff Japanese corporations brought separate suits against the Government to recover additional costs incurred in the construction of U.S. facilities in Japan. In both cases the Government was granted a separate trial on the issue of whether the court's jurisdiction extends to suits against the U.S. by citizens of Japan. Since the identical jurisdictional issue was presented in both actions, the cases were consolidated for hearing and decision on that issue.

In an earlier hearing on the plaintiff Nippon Hodo's claim, 160 F. Supp. 501 (Ct. Cl. 1958), the Government introduced an instrument signed by plaintiff's agents releasing "all claims and demands which the contractor now has." The Court of Claims, through Judge Madden, held that the parties did not intend to execute a release of the claim here in question and denied the government's motion for a summary judgment. Id. at 502. Jones, C.J., vigorously dissented on the contract principle that a court of equity cannot reform an instrument to compensate for the unilateral misunderstanding of a party. Ibid.

${ }_{28} 8$ U.S.C. $\$ 2502$ (1958).

'April 2, 1953, 4 U.S.T. 2063, T.I.A.S. No. 2863, art. IV, sec. 1.

${ }^{5}$ Chief Judge Jones delivered the opinion, with Judges Durfee, Madden and Whitaker concurring. Judge Laramore delivered a separate dissenting opinion stating reasons for his feeling that the government's contention should have been approved. 285 F.2d at 770 .

" "Citizens or subjects of any foreign government which accords to citizens of the United States the right to prosecute claims against their government in its courts may sue the United States in the Court of Claims if the subject matter of the suit is otherwise within such court's jurisdiction.” 28 U.S.C. § 2502 (1958).
} 
American can sue the plaintiff's government on the same type of claim. ${ }^{7}$

The court clearly rejected the government's contention and held that "[Section 2502] contemplates only that Americans enjoy equal standing with foreigners in actions against the foreign government and does not require that the scope of actions for which the respective countries render themselves liable shall be co-extensively identical. ...8 In so holding, the majority of the court reasoned that adoption of the government's contention would add no luster to the "golden rule of conduct" that has long guided our country in its international affairs," and they further expressed doubt that such a position would be in keeping with the attitude of the American people that our country is generous and should be willing to lead and act first. ${ }^{10}$

The court apparently believes that reciprocity is not a theory to be strictly construed in considering the jurisdictional question where foreign plaintiffs have claims against the United States. This becomes apparent when considered in light of the court's lengthy discussion of plaintiff's evidence. ${ }^{11}$ The plaintiffs contended that if Section 2502 required proof of reciprocity in specie, they had made an adequate showing. ${ }^{12}$ The court, having decided that an American need only be able to sue on some type of claim, said, in effect, that even had the government's narrow construction been approved, plaintiffs still would have prevailed.

This dictum strongly suggests that the court is willing to accept rather meagre evidence of the existence of reciprocity. This analysis of the court's atttiude is strengthened by the fact that here the problem

${ }^{7}$ Brief for Defendant, p. 8. Another statutory provision, not available to the Government here, specifically requires reciprocity in specie. Public Vessels Act § 5, 43 Stat. $\operatorname{III}_{3}$ (1925), 46 U.S.C. $\S 78_{5}$ (1958). For interpretation of this statute see Maiorino v. United States, 1 I 1 F. Supp. 817 (S.D.N.Y. 1952); Lopez v. United States, 10z F. Supp. 870 (E.D.N.Y. I952).

${ }^{8} 285$ F.2d at 767,768 .

285 F.2d at 767 .

${ }^{10}$ Ibid.

${ }^{11}$ The opinion of the Commissioner in this case said only that section 2502 did not contemplate reciprocity in specie and did not discuss the findings of fact regarding plaintiff's evidence. "It is not necessary to determine whether the Japanese Government permits itself to be sued in contract actions." Opinion and Findings of Fact of Commissioner Bernhardt, p. 2.

Actions brought in the Court of Claims are first tried before a Commissioner, who submits findings of fact, opinion and conclusions of law to the court under arders of the court promulgated pursuant to Rule 45. CT. Claims R. 45 -

${ }^{12}$ Brief for Plaintiff, p. 9. 
of proving foreign law ${ }^{13}$ was particularly difficult since there were no decided cases in which Japanese courts had entertained a contract suit by an American against the Japanese government. ${ }^{\mathbf{1 4}}$

Absent judicial precedent, it has generally been held necessary to produce statutory evidence of foreign law as well as expert testimony regarding the proper interpretation of the foreign law in question. ${ }^{15}$ Plaintiffs produced constitutional ${ }^{16}$ and statutory ${ }^{17}$ excerpts from which

${ }^{13}$ The problem of proving foreign law was diffcult historically. The common law of England and the United States viewed foreign law as a fact to be pleaded and proved as part of plaintiff's cause of action. The origin of this principle was a feeling that it was unrealistic and impractical to presume the court's knowledge of the law of other jurisdictions. A rigid corollary to this rule was that the court could not judicially notice the laws of a foreign country.

Owing in part to the time, expense and difficulty of introducing into evidence the proof of foreign law and in part to the injustices resulting from technical objections to presentation of otherwise competent evidence, a need for reform appeared. Pursuant to the urging of European and American legal philosophers, legislatures began adopting measures which specifically provided for judicial notice of the law of foreign jurisdictions. The purpose of the statutes thus enacted was to put resolution of the question in the hands of the court rather than the jury and to reduce what were deemed the unnecessary evidentiary formalities of introducing foreign law into the case without abolishing the need for its proof. The trend to legislation of this type has been aided by the adoption in 26 states of the Uniform Judicial Notice of Foreign Law Act. This act allows courts of the enacting state to notice judicially the law of sister states but not that of foreign countries. SOMMERICH \& BUSCH, ForeIgN LAW: A GuIdE To Pleading and ProOF, 1 r-20 (x959).

Under Rule $43(a)$ of the Federal Rules of Civil Procedure, if the instant claim had been brought in a federal district court in a state which statutorily provides for judicial notice of the law of foreign countries, e.g. MAss. GEN. LAws, c. $233, \S 70$ (1956), plaintiff would have had to produce only the Constitutional and statutory excerpts. 5 MOORE, Federal Practice, I43.09 at 1342-5 (2d ed. I95I). Rule 43 (a) was not available in this case, however, since the Court of Claims operates under its own rules rather than under the Federal Rules of Civil Procedure. See Schlesinger, Comparative Law 50 (2d ed. 1959).

${ }^{24}$ Plaintiffs failed to submit translations of any such cases. Further the opinion of the court also seems to indicate that there were no such cases. $28{ }_{5}$ F.2d at 768 .

${ }^{15}$ The case in which English courts first adopted this technique is The Sussex Peerage Case, $x$ I Cl. \& Fin. 85, 8 Eng. Rep. 1034 (H.L. 1844). See cases cited in 7 Wigmore, EVidence $\$ 2090-a(c)$ (3rd ed. 1940).

English courts have required an expert witness regardless of the clarity of the foreign statute involved. The Sussex Peerage Case, supra. Some American courts have been less rigid where the interpretation of the foreign statute is clear. See, e.g., Molson's Bank v. Boardman, 47 Hun. 135, 142 (N.Y. 1888). Accord, Max v. Max, 123 N.J.L. 580, 10 A.2d 163 (1940); Fithian v. Pennsylvania R.R., 9x N.J.L. 275, 103 Atl. 193 (1918); Lorch v. Eglin, 369 Pa. 314, 85 A.2d 841 (1952). See Sommerich \& Busch, The Expert Witness \& the Proof of Foreign Law, 38 Cornell L.Q. $125,148-9$ (1953). See also SoMmerich \& BusCH, supra note 13 , at 43.

10 "Every person may sue for redress as provided by law from the State or a public 
it was only inferable that American citizens had such a right in Japanese courts.

Plaintiffs also offered the deposition of a Japanese attorney in support of their contentions. ${ }^{18}$ The deposition, however, addressed itself to the problem of whether a Japanese citizen could bring a contract suit against his government, ${ }^{19}$ rather than the effect of the constitutional provisions on the rights of American plaintiffs. ${ }^{29}$ The majority had felt that it was only necessary to show that Americans had the same rights in Japanese courts as Japanese citizens. ${ }^{21}$ The dissent pointed out that even assuming this, there was little evidence from which to find that

entity, iu case he has suffered damage through illegal act of any public official." JAPANESE CONST. art. XVII. (Emphasis added.)

"No person shall be denied the right of access to the courts [of Japan]." JAPANESE CONST. art. XXXII.

17 "If a public official entrusted with the exercise of the public power of the State or of a public entity, has, in the conduct of this official duties, inflicted intentionally or through negligence any damages on auother person through an illegal act, the State or the public entity concerned shall be under obligation to make compensation therefor." State Redress Law of Japan art. I (Law No. 125 of 1947).

"Iu cases where a foreigner is the injured party, this statute shall apply only if the compensation is reciprocally gnaranteed." State Redress Law of Japan art. 6 (Law No. 125 of 1947).

Compare III Civil Code of Japan c. I, II, relating to contracts. The chapters contain no specific provision according or denying a right to sue the state or its agents and officials for damage resulting from breach of contract with the state. (Finding of Fact No. 14) Nippon Hodo Co. v. United States, Opinion of the Court, p. yo.

See also, Japanese Court Organization Law (Law No. 59 of 1947), as amended (Law No. 287 of 1950). This statute, which describes the jurisdiction of Japanese courts, contains no specific provision according or denying a right to sue the state or its agents and officials for damage resulting from breach of contract with the state. (Finding of Fact No. 15) Nippon Hodo Co. v. United States, Opinion of the Court, p. $x 0, x x$.

${ }^{18}$ The deposition of Mr. Baba Tosaku, a citizen of Japan and an active member of the Japanese and Tokyo Bar Associations.

10 "A Japanese citizen has the right to sue the Japanese State for breach of contract. . . . In the numerous suits which are continually brought against the State, I have never known of any question being raised whether the citizen can sue the State and $I$ have never heard of such a questiou. Since it is the general opinion of the Japanese Bar that a citizen may bring an action against the State, equally for breach of contract, for payment of salary or damages of other kinds, ..." (Finding of Fact 17). Nippon Hodo Co. v. United States, Opinion of the Court, p. $x 2$.

Compare 285 F.2d at 768 , where the court says: "Plaintiffs produced a deposition from a Japanese attorney, an experienced member of the Tokyo Bar Association, stating in untequivocal language that an American shared equally with a Japanese citizen [the right to sue the government in contract]." (Emphasis added.)

${ }^{20}$ Compare text at note 16 , supra.

22285 F.2d at 767,768 . 
plaintiffs could sue their own government on a contract claim and that, absent convincing proof in this regard, accepting jurisdiction might give them more rights here than they have in their own country. ${ }^{22}$

As further proof plaintiffs offered the reply of the Japanese Minister of Foreign Affairs to inquiries from our State Department concerning the availability of Japanese courts to American citizens. ${ }^{23} \mathrm{Al}$ though the statement was to the effect that American citizens share equally with citizens of Japan the right of access to Japanese courts, ${ }^{24}$ the questionable legal authority of these recitals ${ }^{25}$ renders them little more than conjecture. Thus it appears that the court, while bound to give effect to the reciprocity requirement of the statute, will view evidence of existing reciprocity in a manner that will open the Court of Claims to as many foreign plaintiffs as possible. ${ }^{28}$

The court, by adopting Section 2502 as its ground for decision, chose the broader and more troublesome of two available bases. The same result could have been reached more easily by applying the provisions of the Treaty of Friendship, Commerce and Navigation between the United States and Japan, ${ }^{27}$ and, indeed, plaintiffs had principally relied on it to invoke the court's jurisdiction. ${ }^{28}$ The treaty provides that Japanese nationals shall have the same access to the courts of the United States as do American citizens. ${ }^{29}$ Thus, plaintiffs needed only

22285 F.2d at 770 .

${ }^{23}$ See text at 285 F.2d at 768, nn.3\&5.

24 "Citizens of the United States are given the right equally with the Japanese subjects to institute actions in Japanese courts against the Japanese government in regard to claims arising from such legal relations between citizens of the United States and the Japanese government as belong to the domains of "private law." Dep't of State File, 8 I r.0433/5 I (I925).

"Contractual actions against the Japanese government may be brought by both aliens and Japanese nationals pursuant to general provisions of the Japanese civil and commercial codes." Dep't of State File, 194.3322/7-3 I (1959).

See also text at 285 F.2d at 768, n.4.

${ }^{25}$ Although the foreign law must be proved "to the court's satisfaction," it has been held that no particular type of proof is required. See Nicolas Eustathiou \& Co. v. United States, I54 F. Supp. 515 (E.D. Va. 1957).

${ }^{20}$ This is not to suggest that the court will so view the reciprocity requirement of section 2502 when there is convincing proof that an American has no right of suit in the foreign country. See 285 F.2d at 768 .

${ }^{27}$ April 2, 1953, 4 U.S.T. 2063 , T.I.A.S. No. 2863.

${ }^{28}$ Brief for Plaintif, p. 3 .

20 "Nationals and companies of either party shall be accorded national treatment and most-favored nation treatment with respect to access to the courts of justice and to administrative tribunals and agencies within the territories of the other Party, in all 
to show the applicable treaty sections and that they were covered by it. Resolution of the jurisdictional question under the treaty would then involve the following simple steps: An American citizen may sue the United States on a contract claim; ${ }^{30}$ the treaty grants a Japanese citizen the same rights in our courts; ${ }^{31}$ therefore, a Japanese company may sue the United States on a contract claim. ${ }^{32}$

The Court of Claims apparently refused to adopt the simpler treaty approach in order to reject finally any narrow construction of Section 2502. Moreover, the discussion of plaintiffs' evidence indicates that the court will be open to foreign claimants on the basis of reciprocity given only the slightest evidence upon which such a finding can be sustained. The adoption of such an attitude seems especially proper, as it displays the willingness of the United States to assume leadership in resolving international claims through the judicial process.

degrees of jurisdiction, both in pursuit and in defense of their rights." Art. IV, sec. $x$.

'The term 'national treatment' means treatment accorded within the territories of a party upon terms no less favorable than the treatment accorded therein, in like situations, to nationals, companies, products, vessels or other objects, as the case may be, of such Party." Art. XXII, sec. I.

${ }^{20} 28$ U.S.C. § I491(4) (1958).

${ }^{31}$ See note 30 , supra.

s2 This reasoning may be invoked in the Court of Claims by plaintiffs in seven countries whose governments have treaties identical to the one in this case. Treaty with China, Nov. 4, 1946 [1948], 63 Stat. 1299; Treaty with Ethiopia, Sept. 7, 195x [1953], 4 U.S.T. 2134; Treaty with Federal Republic of Germany, Oct. 29, 1954 [1956], T.x.A.S. No. 35933 Treaty with Greece, Aug. 3, 1951 [1954], 5 U.S.T. 1829, T.I.A.S. No. 3057 ; Treaty with Ireland, Jan. 21, 1950, I U.S.T. 785, T.I.A.S. No. 2155 ; Treaty with Israel, Aug. 23, 195 I [1954], 5 U.S.T. 550, T.I.A.S. No. 2948; Treaty with Italy, Feb. 2, 1948 [1949], 63 Stat. 2255. See 28 U.S.C.A. 2502 (Cum. Supp. 1960).

For a list of United States commercial treaties since 1778 see WiLson, UNITED STATES Commercial Treaties and International LaW App. I, $331-4$ (1960). See WilsoN, supra, at $333-4$, for treaties with Columbia, Denmark \& Haiti, not yet in force, providing similar judicial remedies. 